\title{
THE COOPERATION BETWEEN THE AFRICAN UNION AND THE EUROPEAN UNION IN THE FIELD OF MIGRATION AND COLLECTIVE SECURITY AS AN ABSOLUTE IMPERATIVE
}

\section{INTRODUCTION}

The dialogue between Europe and Africa has reached a new level of high intensity. The recent succession of European meetings, mini-summits with EU Member States, and visits by senior European politicians to the African continent, testify not only to the importance of this dialogue, but also the central place of the subject of migration and security in this dialogue. The demographic, economic and environmental issues underlying the development of the African continent, as well as the migration and security issues, are increasingly structuring the external actions taken by the European Union and the African Union Member States today. This is not a new dimension of Euro-African relations. However, the issue of migration and security has become unprecedented in recent years, which needs to be addressed in the wake of the migration crisis experienced by the EU. In the first place, the Europeans who had not expected the arrival of millions of people were caught off guard, even though these flows were predictable. The concentration of refugees, particularly from Africa, at the gates of Europe, was indeed a situation that posed a threat to the fragile equilibrium. People in Europe are now wondering whether they may also expect a similar migration from Libya and the Sahelian region. Secondly, despite an attempt to establish a common framework in emergency, no solution to this 'migration crisis' has come from an internal political agreement within the EU. A global approach to the issue of migration and security is fundamental for the EU's external policy. It sets out the modalities for the EU's policy dialogue and operational cooperation with third countries in the area of migration and security, on the basis of clearly defined priorities, taking into account the strategic objectives of the EU.

The aim of this article is to examine and assess the current state of EU-AU cooperation in the light of the various challenges originating from the migration and collective security issues. The EU is firmly anchored in the overall framework of its foreign policy development of cooperation, especially in the field of migration and security. It is also important to emphasize that this policy aims at developing mutually beneficial partnerships in line with the interests of the EU and those of the African Union (AU) member states, and 
that it is necessary to ensure effective management of migration flows and the question of collective security. We are assessing the importance of what has happened in the Eastern Mediterranean region to grasp what is happening today in the relations between the EU and Africa. With the 'deal' with Turkey, the Europeans have established a method for drastically curbing the irregular arrivals of migrants, regardless of whether they are refugees or not, instead of solving the migration problem. In the European area, contradictions and limitations are primarily related to the political sensitivity of the issues.

\section{A NEW PARADIGM OF THE AFRICAN UNION - EUROPEAN UNION PARTNERSHIP}

The European Union, as an international organization with a regional scope, is dynamically developing its ability to act on the international arena. ${ }^{1}$ This is happening mainly due to the transfer of some competences to conduct international policy at the level of European Union institutions. ${ }^{2}$ The African continent has always been an area of particular interest for many European countries. Since the establishment of the EEC, economic relations with African countries have been an operative element of its activities. The political dimension of the relations between the EEC and African countries was shaped as changes were introduced into the treaties. Within the basic political and economic dimensions and, more recently, the areas of security and migration, there are several points of mutual interaction: the European Union and individual African states, the European Union and regional economic communities (e.g. ECOWAS) or the European Union and the African Union. The system should also include bilateral links between European and African countries.

Relations between the European Union and the African Union were formally initiated during the first summit held in Cairo (Egypt) in 2000. Since then, we can talk about the existence of a political dialogue based on the adopted institutional solutions which took the form of regular meetings of ministers and senior officials. The establishment of the New Partnership for

\footnotetext{
${ }^{1}$ In contrast to the African Union, the European Union integration process is a complex and long-lasting and multi-branch phenomenon. Today's European Union was created as a result of a multi-stage integration process. The above process was characterized by the transition from negative integration to positive integration. Negative integration concerned the process of removing all trade barriers between Member States, while positive integration was associated with a high degree of coordination and harmonization of national policies of individual EU Member States. This process has become possible thanks to the transfer of some of the competences of the Member States of the European Union. Positive integration consists in changing the decision-making system both at the level of individual Member States and in EU bodies. This integration causes the transition from its lower level, which is the free trade zone to its higher level, which is the Economic and Monetary Union. For more on the subject see Czaplinski (2003): 543; Kawecka-Wyrzykowska (2007): 188.

${ }^{2}$ See Article 47 TUE, Article 356 TFUE.
} 
Africa's Development (NEPAD) in 2001, which led to the creation of the African Union in 2002, was important for the further actions of the European Union, which eventually led to Africa embarking on the path of integration. The emergence of NEPAD and the African Union was considered a turning point and a sign that African leaders are determined to take control and responsibility for change in Africa. ${ }^{3}$

At the Brussels summit in December 2005, the European Council adopted a document called the European Union Strategy for Africa: the Euro-African pact to accelerate development. ${ }^{4}$ It was to be an expression of the coordination of the European Union's policy towards Africa treated as a continent for which specific actions are to be taken. The strategy was, therefore, an expression of the consolidated position and approach of the European Union to the formulation of a policy aimed at Africa as a whole. The strategy also took into account relations at the level of links with other entities, covering a wide range of issues in various selected fields. The Strategy contains provisions on cooperation with the African Union and individual African countries in order to: maintain peace, security and stability, and fight against terrorism and arms trade, ${ }^{5}$ stimulate economic growth; education and health protection; and the protection of human rights. The adopted document was supposed to be a response to the needs of the African continent, assuming that the European Union's policy towards Africa will contribute to the achievement of the UN Millennium Development Goals, such as counteracting poverty, hunger, disease and environmental degradation. ${ }^{6}$

The first years of the strategy's existence were a test for the EU, because the way in which its provisions were implemented and to what extent, would determine further actions to be taken on the African continent. Initially, it was noticeable that they were conducted on the political and operational levels. While the political commitment was based on the principles set out in the strategy, the operational commitment constituted infrastructure and peace support under the African Peace Fund (APF) (e.g. AMIS mission in Darfur),

${ }^{3}$ The New Partnership for Africa's Development (NEPAD) is the pan-African strategic framework for the socio-economic development of the continent. NEPAD was officially adopted by the AU in 2002 as the primary mechanism to coordinate the pace and impact of Africa's development in the twenty-first century. Its primary objective is to provide a new mechanism, spearheaded by African leaders, to: eradicate poverty, place African countries, both individually and collectively, on a path of sustainable growth and development, halt the marginalization of Africa in the globalization process, accelerate the empowerment of women, fully integrate Africa into the global economy.

${ }^{4}$ Bach (2008): 355-370.

5 The European Council underlines the importance of a comprehensive and proportionate response to the threat from terrorism. The European Council adopts the EU Counter-Terrorism Strategy (doc. 14469/4/05 REV 4) which sets out a framework for work to prevent radicalization and the recruitment to terrorism, to protect citizens and infrastructure, to pursue and investigate terrorists, and to improve the response to the consequences of attacks.

${ }^{6}$ On 8 September 2000, following a three-day Millennium Summit of world leaders gathered in New York at the headquarters of the United Nations, the UN General Assembly adopted some 60 goals regarding peace; development; environment; human rights; the vulnerable, hungry, and poor; Africa; and the United Nations which is called Millennium Declaration (Resolution 55/2) 
the AU Nyerere program for higher education and student exchanges, and the Erasmus Mundus program, which was extended to include students from African universities as well. ${ }^{7}$ The Union's strategy was important in the attempts to create the impression of transparency in actions for Africa and to increase the coherence of EU policies by coordinating the activities of the European Commission and the Member States for Africa. The cohesion of EU activities was most visible in the area of the development policy. The EU Member States once again were not uniform at the level of EU institutions and in their positions regarding the imposition of responsibility for helping African countries and different forms of aid sourced from a common budget. However, despite controversies, this solution turned out to benefit both sides. Coordination prevents the duplication of activities and reduces the cost of managing assistance. The Commission's Communication of 27 June 2007 stated that this strategy proved to be useful as a political framework and as a political process. The EU became a better, more united and more effective partner. The strategy was also a stimulus for further actions. Already the fifth meeting of EU and African ministers in December 2005 in Bamako, Mali, indicated the need to bring the partnership between the EU and Africa to a new strategic level and prepare a joint strategy for the European Union and African Union cooperation. It was also recommended that the partnership between the two institutions should no longer continue to be merely the EU's unilateral strategy for Africa. To be effective, sustainable and inclusive, the new strategy had to place job creation at the top of its priorities. Hence the need for new forms and new areas of cooperation, first and foremost in the area of education and training. It is essential to contribute to the building of an Africa of skills, to develop centres of excellence, and to encourage the emergence of an educated, dynamic, employable and active population.

\section{POLITICAL DIALOGUE BETWEEN THE AFRICAN UNION AND THE EUROPEAN UNION}

Since 2007 the Common EU-Africa Strategy has been framing the basis of a political dialogue by defining the "values, interests and goals that are common' to the two institutions. ${ }^{8}$ The re-integration of Morocco into the AU in 2017 helped to establish a parallel EU-AU partnership, at least in appe-

\footnotetext{
${ }^{7}$ In the area of higher education (HE), the priorities agreed for EU-Africa cooperation are to: promote the mobility of students, scholars, researchers and staff; harmonize higher education in Africa; enhance quality assurance and accreditation in African universities; and develop centres of excellence in Africa, in particular through the Pan-African University. The mobility of students, scholars, researchers and staff is to continue to be supported, not least by: the African Union Mwalimu Nyerere Scholarship Scheme; the Intra-Africa Academic Mobility Scheme; and the Erasmus+ programme and the Marie Skłodowska-Curie actions. Harmonization is to be achieved through the Tuning Africa project and quality assurance via the Harmonization, Quality Assurance and Accreditation (HAQAA) programme.
}

${ }^{8}$ Bach (2008): 355-370. 
arance. ${ }^{9}$ However, the institutional limits of the AU restrict the reciprocity of a political dialogue. Although the AU Member states are not ready or willing to give up even a small part of their sovereign right to the AU, it is hoped that they will eventually do so for the sake of the common goal. The adoption of a common position is all the more complicated on sensitive issues such as the migration policy. In its report on the relationships between the African Union and the European Union on the eve of the joint summit in November 2017, the International Crisis Group noted that 'their relationship is essentially that of donor and recipient, but both are reluctant to characterize it as such.' Despite the repeated reference to 'partnerships' or even a 'Euro-African' dialogue, the representatives of African countries suffer from a lack of transparency in terms of Europe's modus operandi and are seldom involved in the drafting of EU external policies which, through the externalization process, will be implemented in African countries and will affect them directly.

Although EU Member States frequently participate in AU's summits, there is no reciprocity when it comes to EU meetings. Moreover, the Euro-African dialogue is often led by certain European Member States, notably France and Germany. The system is still dominated by historic bilateralism which has recently grown even stronger. Although attempts have been made by the EU High Representative to change the hegemony of EU Member States when it comes to European-African talks, it is still these States that continue to lead the political dialogue between Europe and Africa. In spite of this obvious bias, the European Union is seemingly convinced that in the last ten years dialogue has become 'much less ideological and much more concrete.' The European Parliament's report on the revised strategy in 2017 indeed noted that is a 'the development of an equal, long lasting, mutually beneficial relationship.' This approach was also reflected in the central idea of the Abidjan Summit on which it was decided to change the policy and rather than continue the EU's direct funding of development projects in Africa, to promote private investment on the African continent instead.

The underlying goal is to create opportunities for young people to gain education and skills which will help to reduce the structural causes of migration..$^{10}$ The African Union is also aware of the excessive dependency that persists regarding external aid, and of the impediments that this represents for its bargaining power in political negotiations. Hence, AU Member States have made a commitment to increase their contributions to the Continental

9 Van Selm (2002): 143-160.

10 'There is no doubt that in many African countries violent conflict represents a major political and social challenge. Despite their differing constellations, what these conflicts have in common is poor governance and its concomitant side-effects, ranging from corruption and oppression to poor socio-economic participation and a general lack of prospects, which in turn represents a leading cause of insecurity. Poor governance, tends to be closely associated with a loss of legitimacy and authority, favouring a spiral of violence and subsequent conflicts. At the same time, the nature of the conflicts has changed very profoundly. In addition to conflicts perceived as ethno-political, or disputes over power and resource distribution, one is confronted with transnational terrorist violence combined with organized crime, diminishing resources, and climate change: factors that collectively contribute to the weakening of governmental structures.' 
Organization regarding activities related to peace and security. African States are still often silent partners, despite frequent calls voiced by the African civil society for its leaders to assume their responsibilities in migration-related tragedies. However, no joint proposal on the part of the African States has even been drafted to implement a joint response to these challenges.

\section{THE AFRICAN UNION AND THE EUROPEAN UNION ON THE MIGRATION AND SECURITY ISSUE}

The African Union and the European Union promote a constructive and multidimensional approach to migration and collective security challenges in addition to the existing dialogues and frameworks. ${ }^{11}$ The key objectives in this area are to deepen the cooperation between Africa and Europe and to continue the dialogue on migration and collective security, with the objective of addressing the root causes of irregular migration and forced displacement. The EU and AU stress the importance of managing irregular migration effectively, in a spirit of partnership and shared responsibility. ${ }^{12}$ They do so in full respect of national and international laws and human rights obligations, in order to maximize the development potential of both Africa and Europe.

\section{Migration at the heart of Africa-European Union relations}

The context of EU-Africa cooperation has evolved considerably since the 2014 Brussels summit. Migration flows and the refugee crisis are at the heart of the relations between the two continents. ${ }^{13}$ What is more, refugees are also putting pressure on African countries. ${ }^{14}$ The 2015 Valletta Summit on Migration, which brought together European and African leaders and organizations,

11 'The European Council noted the increasing importance of migration issues for the EU and its Member States and the fact that recent developments have led to mounting public concern in some Member States. It underlines the need for a balanced, global and coherent approach, covering policies to combat illegal immigration and, in cooperation with third countries, harnessing the benefits of legal migration. It recalls that migration issues are a central element in the EU's relations with a broad range of third countries, including, in particular, the regions neighbouring the Union, namely the eastern, south eastern and Mediterranean regions, and notes the importance of ensuring that the appropriate level of financial resources is allocated to these policies. The EU will strengthen its dialogue and cooperation with all those countries on migration issues, including return management, in a spirit of partnership and having regard to the circumstances of each country concerned'; Balleix (2013): 296.

${ }^{12}$ Burges (2011): 13-15; Cholewinski (2005): 95-119; Bigo (2005): 77-83; Pascouau (2010): 744.

${ }^{13}$ The term 'migration' refers here to every kind of human movement from one place to another with the intention of settling, permanently or temporarily, whatever the reasons of the movement; in this sense, 'migration' covers both voluntary (labour, family reunification, study) and forced migration; Czaplinski (2003): 543; Dony (2010): 29-59; Kawecka-Wyrzykowska (2007): 188; Wihtol De Wenden, De Tinguy (1995): 13-53.

${ }^{14}$ Fassi, Lucarelli (2017): 12179; Van Selm (2002):143-160. 
marked a turning point in the EU's foreign policy towards Africa, with the discourse now focused on finding solutions to migratory flows and their triggers. The agreement between the EU and Turkey inspired a new EU partnership framework that started in June 2016. Under this framework, tailor-made 'migration pacts' were to be subsequently negotiated by the EU and some African and the Middle East States. However, this agreement was criticized for introducing conditionality. It was also feared that rather than strengthening the cooperation between European and African states, it might create even more suspicion among actors participating in combatting illegal migration. The proponents of the proposed 'migration pacts' praised their multidimensional nature, as they were expected to include both short-term measures to manage continuous flows and asylum applications, and long-term measures to reduce the factors conducive to the migration economic underground. The opponents, on the contrary, believed that reducing poverty was unlikely to reduce migratory flows on its own, since a person requires a minimum of means to migrate. ${ }^{15}$

The above concerns about freedom, security and justice have led EU Member states to include migration in EU security policy issues. ${ }^{16}$ Numerous measures have also been adopted by the EU to protect the territories of the EU Member States and their citizens from the migratory threat. A number of action plans have been implemented, including agencies consisting of border guards and coast guards deployed at the external borders of the European Union and within individual Member States. There were also computerized data control systems of individuals created. However, despite all the efforts taken by the Member States to prevent the arrival of irregular migrants in Europe, the flow has not dried up.

Migrants are determined to come to Europe by all means necessary, even at the risk of their lives. They do not hesitate to embark on makeshift boats to land on the mainland of the Old Continent. They risk their lives, being at the mercy of smugglers who often expose them to life-threatening dangers, such as forcing three hundred of them to travel on a small boat that can only hold one hundred passengers. Sometimes they are abused during their journey, or they find themselves exploited once they reach their destination. However, if they find themselves destitute, they often have no other possibility but to turn to the services of smugglers, trying to obtain false identity documents or to cross the border illegally. Migrant smuggling has thus become a lucrative business fuelled by border closures. Sometimes migrants try ways to get around the authorities and enter Europe on their own. In either case, however, irregular migrants are vulnerable people who are more likely to be exploited. Therefore it is imperative that States reconsider the meaning of the very notion of collective security and integrate it in the concept of human security, in order to provide a framework of full protection of migrants.

15 Kaddous (2010): 61-79; Loescher (2002): 33-45; Huysmans (2006): 208; (2000): 751-777.

${ }^{16}$ L'helgoualch (2011): 317; Van Selm (2002): 143-160; Lavenex (2008): 938-955. 
As can be seen, migration is closely related to the collective security issue. ${ }^{17}$ Consequently, immigration is seen as a problem related to crime and terrorism, and is therefore included in security policy issues. Immigration has become a matter of the internal collective security concerns of individual EU Member states, who wish to control the flow of migrants and to that end have established criteria that must be met by persons authorized to enter their territory.

Under EU Treaties, non-EU citizens who meet these criteria are allowed to enter the territory of EU member States. Once in the EU, they may travel within the Schengen area, but under certain conditions. The lack of border controls between EU Member States has therefore facilitated mobility. However, this openness also facilitates the movement of criminals and people in an irregular situation. This leads to a situation in which data on individuals who have entered Europe irregularly are not available and such individuals will subsequently escape police controls or surveillance. Their activities are on the black market, which often contributes to the spread of other illegal activities. Irregular migration also creates other problems for EU Member States, because undocumented people are more difficult to trace and it is more difficult to understand where they come from, and what their goals and intentions are. Thus, when a person arrives in Europe without documents, it is necessary to determine whether this is for economic reasons or whether the person is fleeing a war or persecution. There are many people who are fleeing ISIS these days. But some migrants are likely to break into Europe to convey the ideology of Daesh. As a result, irregular migration channels may contain harmful elements entering the EU and staying beyond the control and the mechanisms of the security system.

Migration is therefore mingled with security in two ways. It is no longer that it is only the migrants' security that is at stake. It is also the internal security of States that is at stake.

\section{An Africa-European Union strategic partnership for peace and collective security}

In the last decade, Africa has seen a decline in the number of conflicts, and peace reigns over most of its territory today. ${ }^{18}$ The persistent fragility of peace and security and multiple threats to governance and the rule of law have

${ }_{17}$ Megherbi, Aumond (2010): 17-37.

${ }_{18}$ The African Union officially recognizes eight Regional Economic Communities and two Regional Mechanisms with a mandate in peace and security. These are the Economic Community of West African States ECOWAS, the Eco-nomic Community of Central African States ECCAS, the Southern African Development Community SADC, the Common Market for Eastern and Southern Africa COMESA, the East African Community EAC, the Intergovernmental Authority on Development IGAD, the Community of Sahel-Saharan States CEN-SAD and the Arab Maghreb Union UMA, as well as the East African Stand-by Force EASF and the North Africa Regional Capability NARC, African Union and REC/RMs, Memorandum of Understanding, Algiers, African Union, 2008. 
nonetheless demonstrated that multiple crises may lead to devastating conflicts. Storms result from the convergence between the population explosion of the young population, rapid urbanization, water scarcity, other climate-related challenges, omnipresent food insecurity, and delays in industrialization and the development of infrastructural investments. All these factors, which particularly complicate the advent of peace, security and sustainable development in Africa, also have tangible consequences for Europe, particularly in the form of increased flows of irregular migrants. Conflicts and security will therefore remain the chief issues in Europe-Africa relations. The EU has provided essential support for peace and security in Africa over the last decade, against a backdrop of a dramatic increase in security interdependence between the two continents. Most of the EU support has been through the African Peace Facility (APF), which has revitalized peace and security efforts. The funds obtained allowed African security institutions to deploy African troops to ensure peace and stability, with the idea of bringing 'African solutions to African problems. ${ }^{19}$

These solutions include the AMISOM mission led by the AU to carry out coercive operations against Al-Shabab in Somalia and the AFISMA mission led by Africa to stabilize the situation in Mali. Apart from the APF, the EU also manages a number of missions on the African soil under its CSDP. EU-Africa cooperation on peace and security should nevertheless undergo radical changes in the coming years. The EU Political and Security Committee recently called for more balanced FPA funds, with greater emphasis on support for institutional capacity building through the African Peace and Security Architecture (AAPS) of the AU. ${ }^{20}$ This aims to foster greater African ownership of African-led PSOs and a move from crisis-driven funding to longer-term capacity-building in the area of conflict prevention and crisis management. Their reliance on external funding is, moreover, a source of frustration for AU Member States. ${ }^{21}$

Unlike previous roadmaps, there are five objectives with indicators that will be pursued jointly by the AU and the Regional Mechanisms for the operationalization of the AAPS. While the AU seeks to diversify the sources of funding for its activities in the service of peace and security, ${ }^{22}$ the EU itself will have to define the areas where it wishes to support the AAPS, which will constitute a strategic line compatible with the new road. As the AU Peace Fund grows, issues of alignment and coordination will become critical in EU decisions on support for the AU activities from 2017.

All this leads us to the question of the future directions for the Africa-EU partnership in general. Overall, the EU needs to be clear about its role in promoting peace and security. ${ }^{23}$ European actors will have to make a choice in using the APF, either to assert their own security interests or to give African

\footnotetext{
19 Kilingebiel (2005): 35-44.

20 Bachmann (2011): 1-73.

21 Dersso (2010).

22 Williams (2011): 6.

${ }^{23}$ Labayle (2010): 3-27.
} 
organizations the means to deal with their own security problems. To define its strategic position, the EU will at least have a common vision of the APF. The Africa-EU Partnership for Peace and Security has been increasingly institutionalized, notably through a regular dialogue between the AU Peace and Security Council and the EU Political and Security Committee. Doubts still remain as to the strategic value of this partnership. ${ }^{24}$ The EU and the AU do not share the same vision of peace and security. This is partly because the EU's security agenda is largely conditioned by the individual interests of its Member States and partly because EU countries are not accustomed to viewing Africa as an interlocutor that is politically or strategically important. But things are changing: as proof, the 2017 G20 agenda placed great emphasis on Africa. To develop a true strategic partnership, the EU and Africa must move beyond the donor-recipient relationship to a more equitable partnership, based on the same inventory of threats to peace and security.

\section{CONCLUSION}

The implementation of the strategic partnership is a challenge that needs to be addressed. It is essential that that the multilateral and trans-state approach to crisis prevention and resolution of the African continent problem is adopted. This approach is not new and was already advocated in the past. However, it must be complemented not only by a 'bottom up' approach that involves African states investing in multilateral organizations, but also through coordinated support from EU member States to their African counterparts. Perhaps the greatest challenge of the partnership is a joint challenge: to agree upon a common pace of change between the EU and Africa. The political and legal norms of the European Union, the habits of its officials and their method of recruitment, as well as the temporality of current affairs, are far removed from those of an African institution. The mechanisms for cooperation whose foundations remain trust and equitable exchange, should take this into account. The establishment of a cooperation system that would articulate bilateralism and multilateralism, between state and non-state actors such as, for example, African civil society, should be encouraged. With regard to the latter concept, it would still be necessary to specify its definition and involvement in the partnership. From this point of view, the comprehensive approach envisaged by the EU-Africa partnership in the face of its fragility needs to be further explored.

The EU is committed to working alongside all the operational actors to address the complex challenges of migration and human mobility, as well as those posed by mixed flows of migrants, asylum seekers and refugees. The effective return and readmission of persons not in need of protection is a key priority for maintaining the credibility and smooth functioning of our

${ }^{24}$ Koff (2008): 335. 
asylum and migration systems, with full respect for the human rights of migrants and the principle of non-refoulement. In this context, the Commission has recently proposed an ambitious EU Return Action Plan which includes a strategy for intensifying cooperation with immigrants' countries on return and readmission agreements. Encouraging and facilitating voluntary returns to the country of origin remains the preferred solution. Whenever possible, however, the EU is mobilizing all the relevant policies, including its foreign policy as well as its development aid and trade between the two regional organizations, to encourage its partners to cooperate on the readmission issue, in accordance with the 'give more to receive more' principle. To this end, EU cooperation with AU countries will also focus on strengthening the capacity to respond in a timely manner to requests for readmission and on facilitating and speeding up the identification of nationals. At the same time, the EU will invest in supporting the reintegration of returnees and in improving the capacity of the countries of origin of the returnees to help their readmission and reintegration.

\section{Boubacar Sidi Diallo}

Adam Mickiewicz University, Poznań

diallo@amu.edu.pl

https://orcid.org/0000-0002-9124-5569

Bach, D. (2008). The European Union's Strategic partnership' with the African Union, [in:] J. Akokpari, T. Murithi, Angela Ndinga-Muvumba (eds.), The African Union and its Institutions. Fanele \& CCR: Auckland Park and Cape Town: 355-370.

Bachmann, O. (2011). The African Standby Force: External Support to an 'African Solution to African Problem'? IDS Research Report n67, Institute of Development Studies.

Balleix, C. (2013). La politique migratoire de l'Union européenne. Paris.

Bigo, D. (1994). The European internal security field: stakes and rivalries in a newly developing area on police intervention, [in:] M. Andrson, M. Den Boer (eds.), Policing Across National Boundaries. London: 161-173.

Bigo, D. (2005). Le point de vue du politiste, [in:] F. Julien-Laferriere, H. Labayle, Ö. Edstrom (eds.), La politique européenne d’immigration et d'asile: Bilan critique cinq ans après le traité d'Amsterdam. Bruxelles: 77-83.

Burges, J.P. (2011). Security, migration and integration, [in:] J.P. Burges, S. Gutwirth (eds.), A Threat against Europe? Security, Migration and Integration. Bruxelles: 13-15.

Cholewinski, R. (2005). Preventing irregular migration, [in:] F. Julien-Laferriere, H. Labayle, Ö. Edstrom (eds.), La politique européenne d'immigration et d'asile: Bilan critique cinq ans après le traité d'Amsterdam. Bruxelles: 95-119.

Czaplinski, W. (2003). Freedom of movement of goods, [in:] J. Barcz (ed.), European Union law. Warsaw: 543.

Dersso, S.A. (2010). The role and place of the African Standby Force within the African Peace and Security Architecture. Institute for Security Studies Africa. ISS Paper 209. Pretoria.

Dony, M. (2010). Un nouveau cadre normatif, [in:] Ch. Kaddous, M. Dony (eds.), D’Amsterdam à Lisbonne: Dix ans d'espace de liberté, de sécurité et de justice. Basel: 2-59.

Dusch, S. (2002). Le trafic d'êtres humains. Paris.

Fassi, E., Lucarelli, S. (eds.) (2017). The European Migration System and Global Justice. A First Appraisal. GLOBUS Report 1. Oslo.

Huysmans, J. (2000). The European Union and the securitization of migration. Journal of Common Market Studies 38(5): 751-777.

Huysmans, J. (2006). The Politics of Insecurity: Fear, Migration and Asylum in the EU. Abingdon. 
Kaddous, C. (2010). Un nouveau cadre pour la dimension externe de l'espace de liberté, de sécurité et de justice, [in:]: Ch. Kaddous, M. Dony (eds.), D’Amsterdam à Lisbonne: Dix ans d'espace de liberté, de sécurité et de justice. Basel: 61-79.

Kawecka-Wyrzykowska, E. (2007). Economic aspects of free movement of goods in the EU and common commercial policy, [in:] J. Barcz, E. Kawecka-Wyrzykowska, K. Michłowska-Gorywoda (eds.), European Integration. Warsaw: 188.

Kilingebiel, S. (2005). Africa's new peace and security architecture: converging the roles of external actors and African Interests. African Security Review 14: 35-44.

Koff, H. (2008). Fortress Europe or a Europe of Fortresses? The Integration of Migrants in Western Europe. Bruxelles.

L'helgoualch, E. (2011). Panique aux frontières: Enquête sur cette Europe qui se ferme. Paris.

Labayle, H. (2010). La nouvelle architecture de l'espace de liberté, de sécurité et de justice, [in:] Ch. Kaddous, M. Dony (eds.), D’Amsterdam à Lisbonne: Dix ans d'espace de liberté, de sécurité et de justice. Basel: 3-27.

Lavenex, S. (2008). A governance perspective on the european neighbourhood policy: integration beyond conditionality? Journal of European Public Policy 15(6): 938-955.

Loescher, G. (2002) State responses to refugees and asylum seekers in Europe, [in:] A.M. Messina (ed.), West European Immigration and Immigrant Policy in the New Century. London: $33-45$.

Megherbi, N., Aumond, F. (2010). Le PNUD et la sécurité humaine, [in:] R. Kherad (ed.), La sécurité humaine: Théorie(s) et pratique(s). Paris: 17-37.

Pascouau, Y. (2010). La politique migratoire de l’Union européenne. De Schengen à Lisbonne. Paris.

Van Selm, J. (2002). Immigration and asylum of foreign policy: the EU's approach to migrants and their countries of origin, [in:] S. Lavenex, E.M. Uçarer (eds.), Migration and the Externalities of European Integration. Lanham: 143-160.

Wihtol De Wenden C., De Tinguy, A. (eds.) (1995). L'Europe et toutes ses migrations. Bruxelles.

Wihtol De Wenden, C. (2013). La question migratoire au XXIe siècle. Presses de Sciences Po. Joint Communication at the European Parliament and Council: renewed impetus for the EU-Africa partnership (4th May 2017).

Williams, P. (2011). The African Union's Conflict Management Capabilities. New York.

\section{THE COOPERATION BETWEEN THE AFRICAN UNION AND THE EUROPEAN UNION IN THE FIELD OF MIGRATION AND COLLECTIVE SECURITY AS AN ABSOLUTE IMPERATIVE}

\section{Summary}

At a time when Africa is strengthening its attractiveness, acquiring its own story and arousing the interest of new partners, and when Europe is going through an important economic and institutional crisis, what can the new bases for cooperation between the European Union and the African Union be? The Abidjan summit in November 2017 offered an opportunity to reflect on the achievements of bi-regional cooperation between Africa and Europe in the field of migration, peace and security. It emphasized the priority of education, support for sustainable and inclusive development, and multi-sector cooperation, stating that all of them be carried out within the framework of horizontal cooperation favouring reciprocal Africa-European Union contributions. However, one must be aware of the constraints, weighing on both partners, which hinder implementation of the agreed strategies.

Keywords: bi-regional cooperation; European Union; African Union; migration; collective security 